\title{
The Exploration of Resistance in Al-Ramli's Dates on my Fingers and Scattered Crumbs
}

\author{
Saad Zaati Shamkhy ${ }^{1}$, Lajiman Bin Janoory ${ }^{2}$
}

${ }^{1} \mathrm{Ph}$. D. Student in Literature, Faculty of Languages and Communication, University Pendidikan Sultan Idris, Malaysia

${ }^{2}$ Dr, Faculty of Languages and Communication, University Pendidikan Sultan Idris, Tg. Malim Perak, Malaysia

\begin{abstract}
The study discusses the concept of resistance in Al-Ramli's Dates on My Fingers and Scattered Crumbs through the lens of Michel Foucault's theory of power. Resistance is an important component in Michel Foucault's philosophy and plays a key role in his analysis of power. Foucault was keen to make the concept of resistance inherent to the concept of power. Since resistance cannot manage without power. As stated in his book History of Sexuality, Foucault writes "Where there is power, there is resistance and yet, or rather consequently, this resistance is never in a position of exteriority in relation to power" (Foucault,1978, p. 95). The study concluded that there are three different kinds of resistance; tactical reversal in which the resistance is directed by the people against the regime by the adoption of nonviolent activities through for instance disobedience, political revolutions, rebellions, demonstrations, hunger strikes, and the sewing eyes, lips or ears. The second form of resistance is the aesthetics of existence refers to the adoption of the works of arts to resist tyrannical laws and norms. The third form of resistance is violent resistance. The paper also highlights the political oppression and helplessness of the Iraqi people and how the power is abused and utilized by Saddam Hussein's regime for his affairs.
\end{abstract}

Keywords-Resistance, Al-Ramli, Dates on My Fingers, Scattered Crumbs, Foucault's theory of power, Saddam Hussein's regime, The Baath Party.

\section{INTRODUCTION}

The concept of resistance against authoritarian regimes, such as Saddam Hussein's regime can be considered as an essential element in the Iraqi novels, especially the contemporary ones that produced after the fall of Saddam Hussein's government. This revolves around the idea that the Iraqi authors have been freed from the restrictions that the regime was imposed on Iraqi literature. Thus, resistance, political violence, sectarianism were portrayed as the main themes of the recent Iraqi literary works. Iraqi writers such as Muhsin Al- Ramli, Sinan Antoon, Ahmed Saadawi ... etc have provided the readers with prominent contributions to the theme of resistance and political oppression during Saddam Hussein's era. They play a major role to depict and project the Iraqi reality during Saddam Hussein's system.

Al- Ramli has written a novel after a novel, portraying the oppression that the Iraqis faced politically. He uncovered the actualities of Saddam Hussein's regime and to adequately detect the deception and cunning of his ideology. The above two novels stand out among his novels as a good representative to the brutal period that the Iraqis witnessed during Saddam Hussein's regime. His novels also show how Iraqi people express their resistance to his Baath Party (Saddam Hussein's political party). The texts represent the protagonists struggling against a political conflict of the aforementioned regime. Consequently, Al- Ramli is one of the famous Iraqi writers who plays an effective role in exposing the dark times of Iraq history under the rule of the tyrannical regimes.

\section{AL-RAMLI'S LIFE AND WRITING CAREER}

He is officially known as Muhsin Mutlak Rodhan. He is a writer, poet, and translator. Muhsin Al-Ramli is an expatriate Iraqi author living in Madrid, Spain since 1995 He left Iraq after completing his compulsory military service. The cause of his leave was not of the economic situation, but rather to search for freedom. Al-Ramli produced the complete translation of Don Quixote (a Spanish novel) from Spanish to Arabic. Muhsin Al-Ramli is a contemporary Iraqi writer and social activist whose novelistic commitment is directed towards the exposure of socio-political problems affecting his native society. AlRamli, who started the literary scene in 1995, makes the 
novel the main tool to capture the lives of everyday characters affected by diverse types of social problems that result mainly from the dictatorship governments. In 2003, his first novel was published: Scattered Crumbs (2003), a novel where Iraqi history, autobiography, and fiction meet. He decided to write about the political and dangerous situation in Iraq during the dictatorship era of Saddam Hussein. Since then, Al-Ramli has written four novels.

The novels chosen in this dissertation are Scattered Crumbs and Dates on My Fingers. These two novels capture the lives of characters affected by political problems and degradations, such as torture and violence. They are the direct critiques of the degradation of today's culture. The two novels have been translated into English. Muhsin Al-Ramli was awarded the award for his first novel Scattered Crumbs. Also, Al-Ramli is the founder and coordinator of Alwah, a magazine of Arabic literature and thought. Besides the political novels investigated, AlRamli has written short stories such as Gift from the Century to Come (1995), Papers far from the Tigris (1998), The Happy Nights of the Bombing (2003), The Oranges Of Baghdad and Chinese Love (2011). As for poetry, he has written a collection under the title, Asleep among the Soldiers (2011) and We Are All Widowers of the Answers (2005).

In his article under the title 'The author of President's Gardens Reveals Fifty Years Of Oppression and War', Fuad (2016) provides significant information about the author's life and his literary works. Fuad points out that AlRamli has left Iraq after the execution of his brother, the writer Hassan Mutlaq, who was executed by Saddam Hussein's regime because of his opponent ideas of the regime. Thus, the author decided to escape from his country because all the doors were closed in front of him after this event. Al-Ramli declares that the regime prevented him even from publishing the event of killing his brother. However, all those hard conditions would not stop him from being active in his exile. He has accomplished his study at the University of Madrid. He kept writing in press criticising the ideology of The Baath Pary. According to him, the exile helped him more to express his resistant thoughts to Saddam Hussein's government.

\section{METHOD}

With respect to the topic of the study, the researcher utilized Michel Foucault's theory of power to analyze the theme of resistance in Al-Ramli's Dates on My Fingers and Scattered Crumbs. These texts focus on the theme of the present study. This study uses a qualitative method to investigate how the theme of resistance is reflected in the target novels.

\section{TACTICAL REVERSAL AND AESTHETICS OF EXISTENCE RESISTANCE IN AL- RAMLI'S DATES ON MY FINGERS AND SCATTERED CRUMBS.}

Al-Ramli in Dates on My Fingers and Scattered Crumbs portrays the concept of resistance with its two forms. He shows how the characters resist and refuse to accept the ideologies of The Baath Party that are built on force and coercion. His resistance to the sovereign power takes the form of a tactical reversal. As one of the most important of the Foucauldian concept, tactical reversal refers to the kind of resistance that is spontaneous and which achieves without making any hurt to the target government; street protest, hunger strike, and non-obedience or law-breakings are examples of such form of resistance. Tactical reversal and passive resistance can be used interchangeably. Passive resistance is defined as "Organized, nonviolent gatherings of a large number of people to protest against a government, its actions or policies, or one or more of its leaders. Demonstrations that become riots are excluded." (Hibbs, 1973. p.8).

Al-Ramli's tactical resistance is represented in many situations. In his novel Scattered Crumbs, he begins with the narrator who retracing his brothers' steps who already left Iraq searching for freedom. They refused to live in a country in which the autocratic regimes making them living as a marginalized people. And this is a natural effect of this regime to marginalize all advocacy groups that were not cooperate with his system. Thus, they left their country in which they lived their life with wars and conflicts caused by unfair governments; they fled from their country because they had faced extreme oppression under The Baath Party. Their escape plan to prepare a safe for themselves represents their disobedience to the ideology of Saddam's government. It is important to note that the resistant people become strangers among those who were very loyal to the regime. For this reason, the protagonist and his brother Mahmoud do not want anyone to oppress them or stand against their interests. They want to be men worthy of respect. Consequently, their escape of the family into exile is a type of resistance to Saddam Hussein's government. Where the exile becomes their country in which they could find their identity and freedom.

In Scattered Crumbs, the concept of resistance has gained great prominence with many events. For example, AlRamli portrays the Qasim's character as a disobedient character. Qasim did his best in order not to be an easy 
target for the Baath Party abuses. The novel reveals him as the target of the torture and verb abuse from The Party members. However, despite the aim of The Baath Party's power to fulfil its purposes in any way to make anyone loyal and under its control, Qasim, on the contrary, remains a difficult figure. Although they cut one of his ears, the members of the regime still find him an opposed character. Qasim is depicted as an honorable character who cannot be easily exploited by anyone, he did not fear what might happen to him from the government. In an argument with his father about drawing a picture of Saddam Hussein, Qasim says " When the warden asked me [for drawing the leader's picture] to hang on the prison... in exchange for improved treatment and help with my pardon, I couldn't, and he didn't believe me, just like you don't now (Scattered Crumbs, 2003, p.57).

Hence, Qasim's disobedience to his father's desire for drawing the picture of the leader and his disagreement with the latter's different tendencies signifies his refusal of the regime. Besides, the extract above shows that Qasim is confident of his decision, in other words, he does not feel any guilt for his rejection of his father's command, despite his father has great loyalty to The Baath Party government.

Again, Qasim is seen as a source of inconvenience and danger to his father's desires. Qasim's father [Ijayel] as mentioned, has great loyalty to Saddam's regime and dislikes anyone standing against it even if the one was his son. In his love, Ijayel makes no difference between the country and the leader. He says " The Leader is the homeland and the homeland is the Leader" (Scattered Crumbs, 2003, p.58). The son, however, does not succumb to his father's tendency. He asks his father and kisses his palm to give him permission to be free in his decision. Qasim states " No Father, that's TV talk. As for me, I see the opposite, for the leader has destroyed the country" (p.58).

Thus, there are two diverse powers in Ijayel and Qasim's statement above. The first power is represented in the sovereignty of the Baath Party rule and which is manifested in Ijayel's character who insultingly blames his son Qasim for his opposite views towards his father angered the latter, the father says: "Coward Do you call these great victories destruction? You're not a man, and that's why you left your brothers at the battlefront ..." (Scattered Crumbs, 2003, p.58). Furthermore, Ijayel hopes all his sons to be killed in the battle as sacrifices for the leader. Since Ijayel is closer to Saddam than to his sons. The second power is demonstrated in Qasim's character who is portrayed as the main resistant figure that finally indicates the concept of tactical reversal resistance to
Saddam Hussein's regime. For more details regarding the concept of tactical reversal.

In Dates on My Fingers, Al-Ramli once again highlights from the beginning the theme of resistance throughout the story of the narrator's family. Dates on My Fingers first published in Arabic in 2009 then translated into English in 2014. The novel translated into three languages: Italian, Spanish, and English. Saleem Noah, the narrator who left Iraq to settle in Spain looking for a safe place describes the story of how his family resists the dictatorship of the Baath Party regime.

The story in sum, started with Noah, the narrator's father who went with his daughter Istabraq to the hospital, seeking treatment for her illness. The hospital was in the city of Tikrit, the city where Saddam Hussein was born. On their way to the doctor's office, while the father was cleaning a path for his daughter on the market pavement. As a hand stretched out from a window of a black Mercedes which drove past slowly " to grab Istabraq's butt, and a voice was heard: 'Nice ass'" (Dates on My Fingers, 2009, p.2).

Istabraq cried out in terror, and Noah, her father spun around the driver and grabbed his neck, shouting in his face furiously, " you son of a bitch" (p.2). The driver was lifted up by Noah as someone might lift a jar by its neck and pulled out of his car through the window. The driver was dressed in a traditional Arabic robe with a wide leather belt around his waist and a pistol hung down at his side. The driver's car continued its slow walk until it hit another parked car. Meanwhile, Noah rained the driver with blows and curses, who was crying out. He, the driver, says " Do you know whose son I am? " (p2). Noah without stopping the violent blows replied: " Yes I know: your father was a dog, and your mother a whore" (p.2). The driver was recently known as the nephew of the vice president's secretary. Noah, after that took the driver's revolver from its holster, opening the chamber, then he removed three bullets and threw the pistol into the sewer drain. He pulled away the driver's clothes to reveal his ass and began pushing the bullets into his anus.

Based on the extract above, we observe that Al-Ramli attempts to emphasize two important points. The first point illustrates the selfish actions and the bad reputation of the Baath Party members who like to possess everything even if it does not belong to them and this is evident as the character of the driver who abuses the power of the authority for his advantage assault on others. He lacks any sense of humanity and fair and this is so evident in his behavior towards the girl. The second point exposes AlRamli's resistance to tyranny that the government practiced 
on Iraqis. On the other hand, the statement may also incorporate indirect criticism to this tribal revenge which has a considerable impact on tribal society. He intends to call for forgiveness and justice to be spread and to stop committing crimes.

Therefore, in the time in which the resistance for injustice is enhanced by Al-Ramli, his criticism of traditional tribal customs, is equally important. In Dates on My Fingers, he shows this meaning through the character of Mutlaq when he calls to his family saying " If a dog barks at you, don't bark at it; but if it bites you, bite it back" (Dates on My Fingers, 2009, p.3). Mutlaq in this extract reflects the traditional tribal customs that make revenge is the ultimate solution to their conflicts. The dog symbolizes the enemy. Consequently, Al-Ramli, in one way or another mocks such customs to show one important message that the revenge must be limited to the amount of punishment.

The matter above caused Noah to find himself in prison. $\mathrm{He}$ is hardly punished for his resistance. Istabraq remained alone, crying and shaking like a palm branch in the rain. Then, Mutlaq summoned his nine sons, his brothers with their sons, and all his relatives. He said to them " Get your weapons and your cars ready for us to storm Tikrit and break Noah out of prison! For if we keep still when they give us the finger, they will mount up and ride us to the ground" (Dates on My Fingers, 2009, p.5).

Al-Ramili's narration of this novel is different from his Scattered Crumbs novel especially concerning the concept of resistance. Because of the resistance in In Dates on My Fingers changes from the tactical reversal or passive resistance as in Scattered Crumb's novel to violent resistance. Therefore, Al-Ramli's strategy of resistance in this novel indicates that he is slightly different from Foucault's view of resistance. Since, this study emphasizes two forms of resistance, as argued earlier that Foucault presented two concepts of resistance, which are aesthetics and tactical resistance. Therefore, in one way or another, violent resistance is not encouraged by Foucault. However, one of the major issues to be investigated in this novel is pertaining to the Grandfather Mutlaq. He plays a vital role in shaping the lives of his sons and the whole individuals in the village according to his desires and to what he considers appropriate. Mutlaq is proud even of his name. The narrator says "Grandfather Mutlaq, who took pride in bearing the name of our first ancestor, which means "The Absolute'" (Dates on My Fingers, 2009, p.5).

Mutlaq's resistance in Dates on My Fingers embodies, in one way or another, the theme of sovereignty. However, he utilizes the power in its positive form. He normalizes the lives of his people to obey him in everything. He is dominant even upon the naming of all those connected to his lineage. Mutlaq says, " It is God who chose your names, not I" (Dates on My Fingers, 2009, p.29). Thus, many of the people in his village followed this method of naming. He, for example, as soon as a child in his village is born, he immediately opening the Qur'an at random, then he looks at the face of the child, closing his eyes, then he puts his finger on the page, and whatever word his finger landed on will be the name of the new-born.

This method is considered as a habit to be followed by the whole people of the village. Despite the fact that some of the names that have chosen do not constitute acceptance by their owners. An example of that is the narrator's aunt Huda's son, whose father's finger fell upon the word sirat (path) which entailed problems and psychological suffering to him because in school, whenever he left the room, his friends could get his notebooks and they change his name by adding a dot over the first letter of his name to make it a daad instead of saad to call him dirat in Arabic means (fart). Regardless of this, the grandfather Mutlaq's power, as mentioned, is the opposite of Saddam's power. It is characterized by his love for every one of his villages.

It is important to note that both Al-Ramli's novels Scattered Crumbs and Dates on My Fingers discuss and share the theme of rebellion for dignity. The narrator and Qasim in Scattered Crumbs and the grandfather Mutlaq and his son Noah in Dates on My Fingers embody the above meaning. Why did these people revolt? Definitely when they were subjected to oppression and injustice. The narrator in the former, as explained, left Iraq looking for his freedom and to be a man worthy of respect and that leads him to settle outside in a nice environment that detaches him from his hard circumstances. In the same vein, Qasim's resistance to Saddam's government is the most frequently in the text and which is the leading cause of his death. He was executed publicly in front of his family.

Additionally, one observed aspect of Dates on My Fingers is that the power here is represented by the society. Regardless of the power of the regime which the grandfather Mutlaq and his son Noah faced at the end, Mutlaq and all his cousins could resist and speak out against the violent and sexual abuse which they had confronted by one of the Baath Party members. Besides, the resistant power is not merely represented by Mutlaq and his people of his village, there are, instead, many tribes contacting him, such as Kurdish tribes in Makhmur [a town in the north of Iraq] and Arbil [the capital city of Iraqi Kurdistan], and Turkish tribes in Kirkuk. Besides, his Yazidi friends in Sinjar were also tied to him because they have a long-lasting relationship with him. Likewise, an old 
friend from the Christian who also fought with him when they heard about his resistance to the government. This issue indicates that power is not confined to the governments. It is revealed through Michel Foucault's philosophy. Lynch in Michel Foucault Key Concepts states that Lynch " Foucault's theory of power suggests that power is omnipresent, that is, power can be found in all social interactions" (Lynch,2011, p.15).

Al-Ramli adds further that the resistance in Dates on My Fingers has led the government of the Bath Party regime to change all the surnames of the people in the village from "al-Mutlaq to al-Qashmar" (p.9). The word al-Qashmar, in the Iraqi dialect, has the meaning of irony, contempt, and insult. This meaning is highlighted by the narrator when he reveals that "[al-Qashmar] is applied to those who are said to be oblivious and stupid" (p.9). This matter causes pain to all the citizens of the village and makes the resistance to the regime is the most conspicuous one in Dates on My Fingers novel.

Ironically, Al-Ramli mocks the city in which Saddam Hussein born. For instance, in a conversation with the grandfather Mutlaq and his people when they plan to attack Tikrit, he says " I used to know Tikrit when it was a small village, with its red earth covered with rats and its donkeytrading shepherds. So, where is the prison?" (p.6).

The extract exemplifies Al-Ramli's complaint about the reality of the Baath Party regime which has kept the readers in touch with the history of Saddam Hussein. The author is not satisfied with anything of this regime. The Iraqi leadership under Saddam's government is failing to fulfill its promises of a worthy life for the Iraqi people. Iraq becomes a police state ruled by Saddam and his Baath Party which is a source of inconvenience for the Iraqis. Mutlaq arrested and his beard and mustache had been shaved. " His left leg was crippled: the foot was twisted and swollen with burns because they had applied electricity so many times" (p.11).

Another important extract that recounts the resistance in Dates on My Finger's novel is when Saleem, the narrator, meets his father in his exile. The former says " I'm thinking about writing a novel about our village, but I'm reluctant to expose its shame" (Dates on My Fingers, 2009, p.22). The father told him " Write whatever you want. Nothing will happen worse than has already happened" (p.22). This example demonstrates the theme of resistance in its aesthetics form which is realized outside. As regards the word 'shame', it does not refer to the issue that the village is frail and their people are obedient, on the contrary, it revolves around the situation when the regime ordered to change their surnames from "al- Mutlaq to al
Qashmar" (p.9). A matter, as noted, causes pain to all the people of the village.

Moreover, changing the surnames is among the most important factors that enhance the issue of resistance of the grandfather Mutlaq's character, he states " Now come! Let us build a village that we will call Qashmars today so that we will not forget. And after the vengeance, we will call it Freedom, or Dignity, or The Absolute" (p.13). A very important point that Al-Ramli reveals through Mutlaq's quote is the ability in arousing the feeling of love in the heart of his people for their village to defend it. "Strike them with an iron fist, wherever you are able! Bear patiently the disgrace of your surname Qashmar until you take revenge" (p.13). The grandfather Mutlaq recognizes that the aim he endeavors to achieve is very sacred and deserves his struggle and suffering. He eventually killed along with the seventeenth of his relatives.

The next example of Noah's conversation with Saleem, the narrator, also highlights the concept of resistance

"What do you write, poetry?"

" A few poems. But I'm better at short stories. I've published a few of them in the Iraqi opposition newspapers in London."

" The opposition" (Dates on My Fingers, 2009, p.21).

Here, Saleem shows that he has the desire to publish in the Iraqi opposition newspapers which is another reason that can help us to describe him[Saleem] as a resistance character. Again, choosing the Iraqi opposition newspapers as a window of his publication reflects Saleem's cultural resistance to the ideology of the Bath Party regime.

The world that Al-Ramli painted in his novel Dates on My Fingers is full of freedom, though, resistance, and national sense. He in a beautiful and expressive narrative could reveal the ugliness of the daily life in Iraq during the Saddam Hussein era. Although the novel included several events represent tolerance and reconciliation, the theme of revenge is the essential point in the novel. The grandfather Mutlaq is the main character of the novel and his wisdom and storytelling serve as a means of resistance. " Never forget your vengeance" (Dates on My Fingers, p.13). Mutlaq's verbal art was the motivation that encouraged the people of his village in resisting the ideology of The Baath Party. He states:

Let the Qur'an be your school; let the truth guide your words; let freedom be your goal; let patience be your mode of life; let honesty be your language; let work be your habit, and let remembrance be your rule!... I declare that it unlawful for you to eat food made in factories, to work for the tyrannical government, to wear the uniform of 
the police, or to spill each other's blood (Dates on My Fingers, 2009, p.13).

Subsequently, Mutlaq's art of speech has importance in the mind of his people. Its importance lies in its bonding all the people of the village together. As a result, as noted, the people come together in resisting the disturbing incidents that were carried out by Saddam Hussein's system.

Based on the discussion above, Mutlaq's art of speech that encourages the populace to resist can be deemed as aesthetics of existence, since in this form of resistance Mutlaq as the head of the clan utilizes special strategies and arts to conform his resistance. He takes advantage of his people's enthusiasm and their rush to defend their honor to convey his revolutionary ideas. Wisdom is represented and conveyed when Mutlaq narrating his resistant ideas, he states " The Bedouin man took his vengeance after forty years, and he said I have made good time" (Dates on My Fingers, p.11). This statement shows that Mutalq is more careful in revealing his resistance to the government of The Baath Party. Since the vengeance in the Bedouin society is of great interest, the Bedouin man's great happiness is achieved when he takes his vengeance. It gives rise to encouragement and strength for himself. In the same vein, the vengeance in the Bedouin society has special rules and norms, that the killer must be well and not madman, an old man, or a child. The sleeper is not killed unless he is awakened and called in his name three times so that his neighbor hears so that the vengeance will not be insidious.

Theoretically speaking, Michel Foucault discusses the meaning of political oppression and how power is exploited to oppress people. He explains the different techniques of power used by governments or states to control the people. For instance, in Discipline and Punish: The Birth of the Prison (1995), Foucault starts with describing the historical shift of power and punishment practices from the mid-eighteenth to the mid-nineteenth century. To him, power is chronologically divided into three major kinds: sovereign or juridico-discursive power, disciplinary power, and biopower.

\section{CONCLUSION}

The study analysed two selected novels, Scattered Crumbs (2003) and Dates on my Fingers (2009) by Muhsin AlRamli. The focus is on Al-Ramli's portrayal of how the characters are resisted to The Baath Party (Saddam Hussein's political party). The study has concluded that there are three forms of resistance that have been embodied in Al Ramli's selected texts; tactical reversal, aesthetics of existence and violent resistance. The researcher has examined all of these forms as depicted through the characters of the target novels.

\section{REFERENCES}

[1] Al-Ramli, M. (2003). Scattered Crumbs (Translated by Yasmeen. S. H). U.S.A: University of Arkansas press.

[2] ... (2009). Dates on My Fingers (Translated by Luke. L). Cairo: The Amerian University in Cairo Press.

[3] Foucault, M. (1978). The History of Sexuality. Vol. 1, An Introduction. Translated by Robert Hurley. New York: Pantheon.

[4] Foucault: Key Concepts (pp. 13-27. Ashford Colour Press Ltd, UK.

[5] Foucault. M. (1995). Discipline and punish: The birth of the prison (2nd ed.). Vontage Books. New York.

[6] Fuad, S. (2016) The author of President's Gardens Reveals Fifty Years of Oppression

[7] and War. Retrieved from http://alramliarabic.blogspot.com/2016/05/blog-post_8.html

[8] Hibbs, D. A. (1973). Mass political violence: A crossnational causal analysis (Vol. 253). New York: Wiley.

[9] Lynch, R. A. (2011). Foucault's Theory of Power. In Taylor, D. (Eds.) Michel 